Original Research Paper

\title{
Pemberdayaan Kader Desa dalam Upaya Mewujudkan Tercapainya Status Open Defecation Free (ODF) di Desa Kuranji Dalang Kecamatan Labuapi, Lombok Barat
}

\author{
Ida Ayu Eka Widiastuti ${ }^{1}$, Rifana Cholidah ${ }^{2}$, Siti Rahmatul Aini ${ }^{3}$, Putu Aditya Wiguna $^{4}$, Ida Bagus Alit ${ }^{5}$
}

1Department of Physiology, Faculty of Medicine Universitas Mataram, Mataram, Indonesia
2Department of Nutrition, Faculty of Medicine Universitas Mataram, Mataram, Indonesia
3Department of Farmacology, Faculty of Medicine Universitas Mataram, Mataram, Indonesia
4Department of Paediatrics, Faculty of Medicine Universitas Mataram, Mataram, Indonesia
5Department of Mechanical Engineering, Faculty of Engineering Universitas Mataram, Mataram, Indonesia

DOI: https://doi.org/10.29303/jpmpi.v3i2.502

Sitasi : Widiastuti, I. S. E., Cholidah, R., Aini, S. R., Wiguna, P. A., \& Alit, I. B. (2020). Pemberdayaan Kader Desa dalam Upaya Mewujudkan Tercapainya Status Open Defecation Free (ODF) di Desa Kuranji Dalang Kecamatan Labuapi, Lombok Barat. Jurnal Pengabdian Magister Pendidikan IPA, 3(2)

Article history

Received: 29 September 2020

Revised: 25 Oktober 2020

Accepted: 19 November 2020

*Corresponding Author:

Ida Ayu Eka Widiastuti,

Faculty of Medicine

Universitas Mataram, Mataram,

Indonesia;

Email: ayueka@unram.ac.id

\begin{abstract}
Desa Kuranji Dalang merupakan desa binaan Puskesmas Perampuan, Labuapi Lombok Barat. Desa ini juga merupakan desa binaan bagi Badan Eksekutif Mahasiswa (BEM) Fakultas Kedokteran Universitas Mataram. Pemilihan ini didasarkan pada data Dinas Kesehatan Lombok Barat bahwa Desa Kuranji Dalang merupakan salah satu desa dengan tingkat sanitasi terendah di Lombok Barat. Hal ini dibuktikan dengan belum tercapainya status Open Defecation Free (ODF) atau bebas dari buang air besar sembarangan. Dalam rangka mewujudkan tercapainya status ODF bagi Desa Kuranji Dalang maka kader desa memiliki peran strategis. Kegiatan pengabdian masyarakat ini bertujuan untuk memberikan penyegaran bagi kader desa tentang STBM (Sanitasi Total Berbasis Masyarakat), terutama tentang perilaku BAB (buang air besar) dan sanitasi jamban sehingga nantinya dapat mentransfer pengetahuan yang diperoleh kepada warga binaannya.Kegiatan dilaksanakan melalui 2 (dua) tahapan, yaitu penyusunan modul dan pelatihan/penyegaran. Modul berisi materimateri yang berkenaan dengan perilaku hidup sehat dengan lebih difokuskan pada perilaku buang air besar. Penyegaran dibagi dalam 2 sesi, yaitu sesi penyampaian materi dan sesi diskusi/tanya jawab. Kegiatan yang mengambil tempat di Puskesmas Perampuan ini diikuti oleh 20 orang kader Desa Kuranji Dalang dan dilaksanakan bekerja sama dengan pihak Puskesmas Perampuan. Kader desa telah menjalankan perannya terkait upaya mewujudkan Desa Kuranji Dalang dengan status ODF, seperti melakukan pendataan rumah dan penyuluhan. Kendala utama yang dihadapi adalah masih rendahnya kesadaran masyarakat untuk menerapkan perilaku hidup bersih dan sehat, khususnya untuk tidak BAB sembarangan. Dengan demikian diperlukan upaya yang lebih komprehensif dengan melibatkan pihak-pihak terkait.
\end{abstract}

Kata Kunci: Open Defecation Free (ODF), Kader desa, Perilaku hidup sehat 


\section{Pendahuluan}

Calah satu upaya partisipasi mahasiswa FK - Unram dalam kegiatan pengabdian masyrakat adalah dengan membentuk sebuah desa binaan sebagai lahan bagi para mahasiswa melalui Badan Eksekutif Mahasiswa (BEM) untuk melaksanakan kegiatan pengabdian masyarakat. Desa yang dipilih adalah Desa Kuranji Dalang, yang peresmiannya telah dilakukan pada Oktober 2013 lalu. desa Kuranji dalang merupakan Desa yang terletak di Kecamatan labuapi, Lombok Barat, mataram, namun bukan berarti tidak memiliki masalah kesehatan yang perlu mendapat perhatian dan membutuhkan penanganan segera. Berdasarkan data dari Dinas Kesehatan Lombok Barat tahun 2013, Desa Kuranji Dalang merupakan salah satu Desa dengan tingkat sanitas terendah di Lombok Barat. Hal ini dibuktikan dengan belum tercapainya status Open Defecation Free (ODF) atau bebas dari buang air besar sembarangan, yaitu suatu kondisi ketika setiap individu dalam komunitas tidak buang air besar sembarangan.

Stop buang air besar sembarangan (Stop BABS) merupakan salah satu pilar STBM (Sanitasi Total Berbasi Masyarakat) merupakan program nasional dari Kementrian Kesehatan Republik Indonesia yang dicanangkan sejak tahun 2008 sebagai sebuah upaya untuk mempercepat peningkatan akses sanitasi. Pencanangan ini ditandai dengan ditetapkannya Keputusan Menteri Kesehatan Nomor 852 pada September 2008. CLTS (Community Led Total Sanitation) digunakan sebagai metode andalan dalam pelaksanaan STBM. Dikeluarkannya Kepmenkes STBM ini erat hubungannya dengan upaya bangsa Indonesia untuk memenuhi komitmennya untuk mencapai target MDGs (Millennium Development Goals) khususnya terkait butir 7 yaitu untuk mengurangi minimal separuh penduduk yang tidak terakses sanitasi dasar pada tahun 2015 nanti.

Desa Kuranji Dalang merupakan desa yang terletak di bawah binaan Puskesmas Perampuan. Di desa ini telah terbentuk beberapa orang kader kesehatan, yang secara langsung dibina oleh pihak Puskesmas Perampuan. Melalui kegiatan pengabdian masyarakat ini diharapkan kader-kader yang ada dapat lebih diberdayakan dalam mempercepat pencapaian status ODF mengingat Desa Kuranji Dalang merupakan desa yang belum mendapatkan status ODF (Open Defecation Free) dengan persentase akses jamban yang memenuhi standar paling rendah

\section{Metode}

Dalam rangka mencapai tujuan kegiatan dan target luaran, maka pelaksanaan kegiatan pengabdian ini terbagi dalam beberapa tahapan kegiatan, yaitu:

1. Penyusunan modul

Modul ini berisi materi-materi yang berkenaan dengan perilaku hidup sehat dengan lebih difokuskan pada perilaku buang air besar. Modul ini disusun sebagai instrumen/alat yang dipakai dalam pelatihan bagi para kader desa/dusun.

2. Pelatihan/Penyegaran Kader

Kader-kader desa/dusun yang telah ada, diberikan pelatihan atau penyegaran tentang perilaku hidup sehat dan STBM (sanitasi total berbasis masyarakat).

Sasaran utama dari kegiatan ini adalah kader desa Kuranji Dalang. Para kader akan lebih diberdayakan dalam upaya mencapai tujuan akhir, yaitu Desa Kuranji Dalang yang bebas dari buang air besar sembarangan.

\section{Hasil dan Pembahasan}

Kegiatan pengabdian masyarakat, berupa penyegaran bagi kader desa tentang PHBS (Perilaku Hidup Bersih dan Sehat) dan STBM (Sanitasi Total Berbasis Masyarakat) dengan menitikberatkan pada perilaku buang air besar dan sanitasi jamban ini dilaksanakan pada hari Sabtu, tanggal 22 November 2014, bertempat di ruang pertemuan Puskesmas Perampuan. Kegiatan penyegaran ini diikuti oleh 20 orang kader Desa Kuranji Dalang, Desa Kuranji Dalang merupakan salah satu desa binaan Puskesmas Perampuan.

Kegiatan dilaksanakan dalam 2 sesi yaitu sesi penyampaian materi oleh tim pengabdian masyarakat dan sesi diskusi/tanya jawab. Di selasela sesi diskusi para kader juga diberikan kesempatan untuk menceritakan pengalaman mereka dalam menjalankan peran mereka sebagai kader di lapangan, terutama kendala-kendala yang mereka hadapi. Dengan tujuan untuk mempermudah penyerapan dan pemahaman peserta terhadap materi, maka beberapa slide dibuat dalam bentuk gambar/animasi. Setelah sesi penyampaian 
materi, dilanjutkan dengansesi tanya jawab dan diskusi.

Pada saat penyampaian materi, terlihat antusiasme peserta untuk menyimak materi cukup baik, beberapa bahkan membuat catatan, demikian pula halnya pada sesi diskusi. Pada sesi diskusi pertama maupun kedua, masing-masing terdapat 4 orang penanya. Dalam sesi diskusi ini tim juga dibantu oleh seorang petugas Puskesmas Perampuan bidang sanitasi untuk memberikan penjelasan dan pemahaman tentang hal-hal terkait sanitasi yang menjadi pertanyaan para peserta. Di sela-sela sesi diskusi ini, beberapa kader desa menyampaikan peran apa saja yang telah mereka jalankan selama ini, di antaranya adalah melakukan pendataan rumah di wilayah binaannya, berapa rumah yang telah dan belum memiliki jamban, berapa yang memiliki jamban yang memenuhi standar kesehatan dan berapa yang rusak. Di samping itu mereka juga menyampaikan kendala mereka dalam menjalankan peran mereka sebagai kader, di antaranya adalah masih rendahnya kesadaran beberapa warga untuk buang air besar yang sehat atau dengan kata lain masih ada warga desa yang memilih untuk BAB tidak di dalam jamban, namun di sungai, di kebun atau di tepi pantai. Secara geografis letak Desa Kuranji Dalang dekat dengan pantai. Menurut para kader, alasan warga adalah agar lebih mudah dan murah. Hal ini menjadi tantangan tersendiri bagi para kader.

Pihak Puskesmas Perampuan melalui para kader telah melakukan upaya untuk mewujudkan Desa Kuranji Dalang yang bebas BAB sembarangan (BABs). Upaya yang dilakukan di antaranya adalah dengan memberikan penyuluhan kepada warga binaannya, baik pada waktu Posyandu maupun pada kegiatan-kegiatan yang mendatangkan warga dalam jumlah yang cukup banyak sehingga mampu mentransfer pengetahuan tentang jamban sehat dan perilaku BAB kepada warga desa

Melalui kegiatan penyegaran tentang PHBS dan STBM ini diharapkan pengetahuan para kader tentang materi ini semakin baik sehingga mampu menjalankan perannya sebagai lini terdepan pemberi informasi bagi warga di daerah binaannya. Peran kader sangatlah besar dalam membantu pihak puskesmas mensukseskan program-program yang telah direncanakan, termasuk mewujudkan Desa Kuranji Dalang yang ODF (open defecation free).

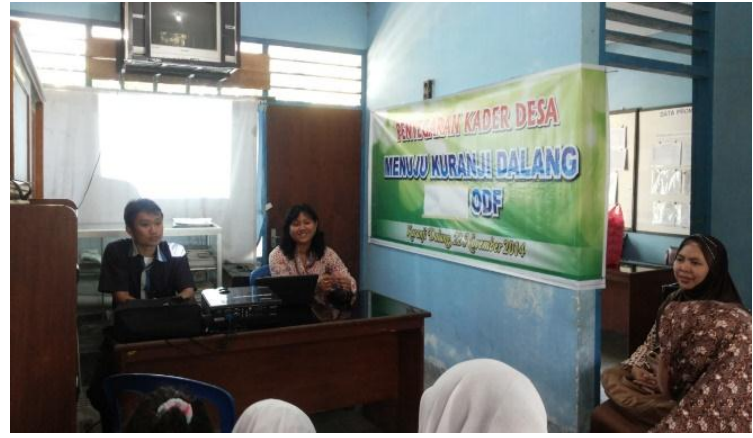

Gambar 1 Penyampaian Materi Pelatihan

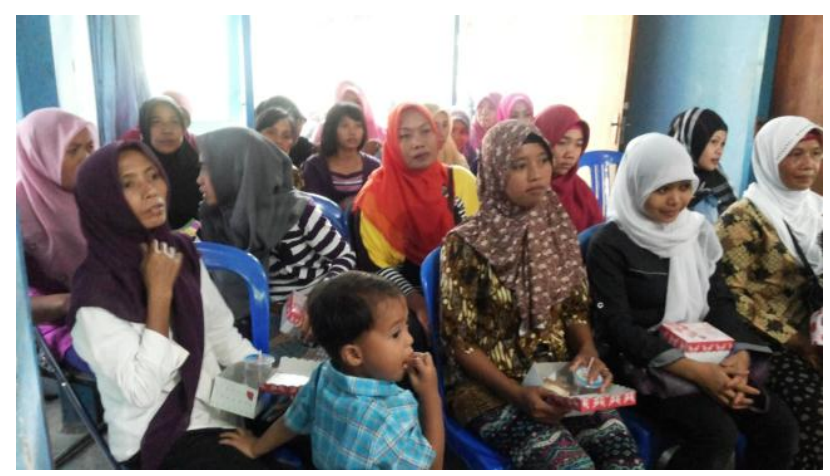

Gambar 2 Kader Peserta Pelatihan/Penyegaran
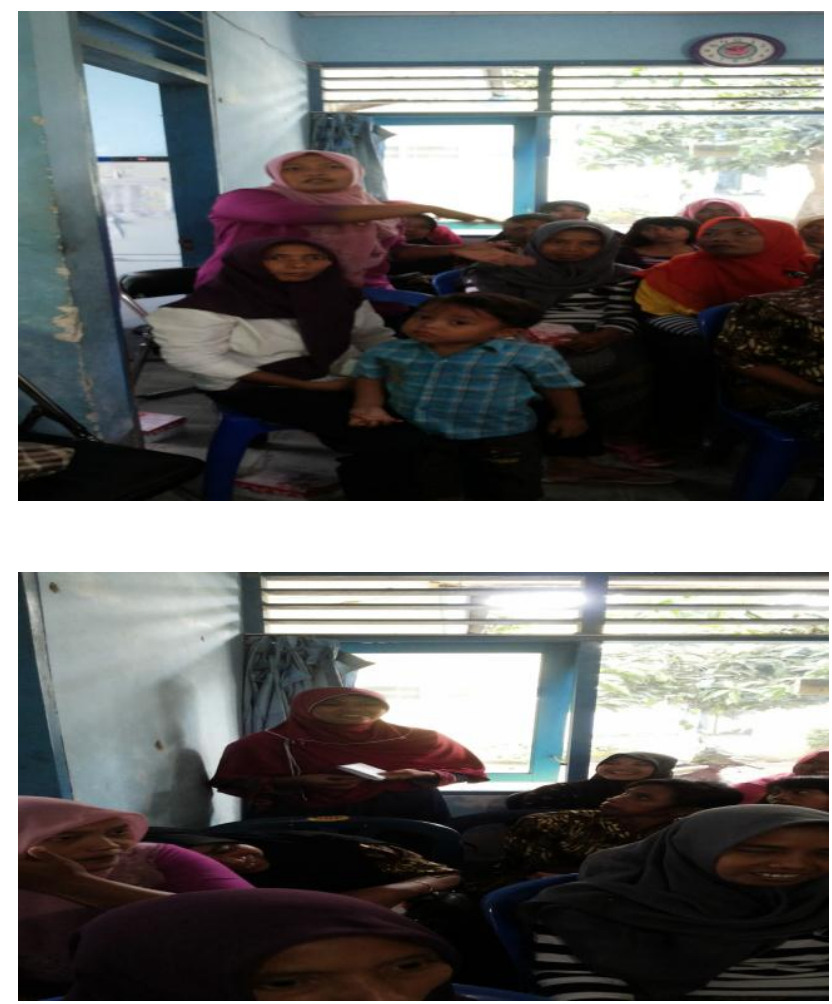

Gambar 3 Sesi Tanya Jawab 


\section{Kesimpulan}

1. Para kader desa di bawah binaan Puskesmas Perampuan telah melaksanakan perannya kepada warga binaannya dalam hal penyuluhan dan pendataan terkait STBM (Sanitasi Total Berbasis Masyarakat), termasuk tentang perilaku buang air besar dan sanitasi jamban, namun masih cukup banyak kendala.

2. Kendala utama yang dihadapi para kader adalah masih rendahnya kesadaran warga dalam melaksanakan perilaku buang air besar yang sehat dalam kehidupan sehari-hari.

3. Kader desa dengan arahan puskesmas dan dibantu dengan adanya program desa binaan BEM Fakultas Kedokteran Unram bekerja sama dalam upaya mewujudkan Desa Kuranji Dalang dengan status ODF (open defecation free).

\section{Ucapan Terima Kasih}

Penulis mengucapakan terima kasih kepada pihak Puskesmas Perampuan dan Aparat Desa Kuranji Dalang Kecamatan Labuapi Lombok Barat atas dukungannya sehingga kegiatan pengabdian ini dapat terselenggara dengan baik.

\section{Daftar Pustaka}

Anonim. Sanitasi total berbasis masyarakat. Available at: http://sanitasitotalberbasismasyarakat.wordpress.co $\mathrm{m} / 2012 / 12 / 26 / 5$-lima-pilar-stbm-sanitasi-totalberbasis-masyarakat/ [Acceseed 10 Maret 2014].

Departemen Kesehatan Republik Indonesia, 2008. Strategi Nasional Sanitasi Total Berbasis Masyarakat [pdf] Available at: http://stbmindonesia.org/dkfaq.php

Irwantoro, W. CLTS sebagai metode andalan dalam pelaksanaan STBM. Available at: http://www.stbmindonesia.org/dkconten.php?id=2549. [Acceseed 10 Maret 2014].

Data Dinas Kesehatan Lombok Barat tahun 2013

Data Puskesmas Perampuan Lombok Barat tahun 2013 